\title{
Globalization And Religion
}

David Skinner, (Email: dskinner@mvnu.edu), Mount Vernon Nazarene University

\begin{abstract}
This paper empirically examines whether globalization has a religious dimension. As far as the author can determine, no one has previously tested the question. The study concludes that publicly available databases show that much of globalization, or lack of it, can be predicted from data on the religions practiced in a nation.
\end{abstract}

$T$

he events of September eleventh remind us that all religions are not alike. The religions practiced in a nation appear to have significance in the nation's political, social and economic arenas.

Much discussion has focused on whether globalization's overall impact is healthy or not. This research bypasses that issue to examine whether nations' globalization can be explained by the religions practiced by their citizens.

This paper uses Policy Magazine's Globalization Index (Globalization, 2002) as a globalization metric and data from the World Christian Encyclopedia (2001) as a measure of the distribution of various religions.

Univariate results indicate that nations with higher percentages of Christians, Protestants, Great Commission Christians, the nonreligious, and atheists exhibit greater globalization. Those with higher percentages of Muslims are less globalized.

When combinations of religions are considered, Great Commission Christians, Pentecostals/Charismatics, Ethnoreligionists, Protestants, Jews, and total Christians collectively, explain much of countries' Globalization Index.

Section I discusses the literature, Section II examines the data sources, Section III describes the methodology used, Section IV reports the findings, and the last section provides conclusions.

\section{Section I: Literature Review}

If all of the ten countries set to enter the European Union are admitted, it will form a 444 million-customer bloc (European, 2002). NAFTA has already created a market with 387 million customers. The GDPs of the two groups are estimated to be $\$ 8.4$ Trillion and $\$ 11.4$ trillion, respectively.

Lavin (2002) notes that "thanks largely to the fact that a decent education, Microsoft Office, and the Internet are all as useful in Manila as Minneapolis, the service sector has gone mobile." International movement of many services is limited only by the cost of communication, and that has become virtually free.

After the October 2002 bombing of discos in Bali, a Florida travel agent said "her clients are increasingly asking about the religious makeup of destinations. 'They really think about non-Muslim countries,"' (Skittish, 2002)

Melloan (2002) reports that "only a very small percentage of the American workforce feels threatened by 'cheap labor' abroad. And a fairly large percentage of the American polity understands that erecting trade barriers

Readers with comments or questions are encouraged to contact the author via email. 
or subsidizing selected domestic industries with tax dollars makes everyone poorer." At the same time, the antiglobalization movement has been supported by organized labor.

In his review of Daugherty's Who's Afraid of Adam Smith, McMahon (2002) notes that those opposed to globalization claim that capitalism is synonymous with unbridled greed. However, Adam Smith was trained as a moral philosopher. He believed that markets forced people to be concerned about how they were viewed by others. "Far from rewarding naked greed, the market encourages probity, temperance and fair dealing. The fear of losing customers restrains 'frauds' and corrects 'negligence.' In trade as in life, Smith avowed, 'honesty is the best policy." Smith gave much of his own fortune to charity.

Foreign Policy Magazine and A. T. Kearney, Inc. produce the Globalization Index, which evaluates nations on economic integration, personal contact, technological connectedness, and political engagement (Gray, 2002). The current version of the Index evaluates sixty-two countries comprising $85 \%$ of the world's population and $90 \%$ of the world's economic output. The originators of the Index have found that the greater a nation's globalization the greater its income equality and political freedom and the lower its corruption. Higher globalization is also positively correlated with the World Values Survey of "subjective well-being". Government taxing and spending levels are highly correlated with each other but uncorrelated with globalization. And, globalization is not correlated with the size of a country's economy.

A paper by the present author finds that $28.6 \%$ of the Index of Economic Freedom of nations can be explained by the religions practiced in those nations (reference omitted for blind reviewing). Therefore, it is possible that globalization, which is at least partly economic, may also be related to religion.

\section{Section II: Data Sources}

The Globalization Index Published by Foreign Policy Magazine in cooperation with A. T. Kearney, Inc. (hereafter called the Index) is a composite of several factors. It includes:

- $\quad$ Economic integration by combining data on trade, foreign direct investment and portfolio capital flows, and income payments and receipts....

- Personal contact via levels of international travel and tourism, international telephone traffic, and crossborder transfers....

- $\quad$ Technological connectedness by counting Internet users and the Internet hosts and secure servers....

- $\quad$ Political engagement by taking stock of the number of international organizations and U.N. Security Council missions in which each country participates, as well as the number of foreign embassies that each country hosts. (Gray, 2002).

The distribution of various religions is obtained from the World Christian Encyclopedia (2001). Other sources were discarded since each excluded many of the countries in the Index or only gave a listing of religions without numbers. This source gives percentage breakdowns by various Christian categories and several other religions. The Christian categories are not mutually exclusive. For example, denominational categories (i.e.: Roman Catholic, Protestant, etc.) overlap with other types (i.e.: Evangelical, Pentecostal/Charismatic, etc.). Also, some individuals may practice more than one religion (e.g.: Some in the Caribbean practice both Roman Catholicism and Voodoo). Furthermore, religions are self reported and may be biased. These facts must be kept in mind when interpreting the results.

Some religions are clearly defined while others need to be clarified. The definitions below are verbatim from the World Christian Encyclopedia (2001).

Independents. Separated from, uninterested in, and independent of historic denominationalist Christianity.

Evangelicals. A subdivision mainly of Protestants consisting of all affiliated church members calling themselves Evangelicals, or all persons belonging to Evangelical congregations, churches or denominations: characterized by commitment to personal religion. 
Charismatics. Baptized members affiliated to nonpentecostal denominations who have entered into the experience of being filled with the Holy Spirit.

Great Commission Christians. Believers in Jesus Christ who are aware of the implications of Christ's Great Commission, who have accepted its personal challenge in their lives and ministries, are attempting to obey his commands and mandates, and who are seeking to influence the body of Christ to implement it.

Ethnoreligionists. Followers of a non-Christian or pre-Christian religion tied closely to a specific ethnic group, with membership restricted to that group; usually animists, polytheists, or shamanists. Older terminology: pagans, heathens, tribal religionists, traditional religionists. [In this paper the term is also used to include Chinese folk religionists and spiritists.]

Nonreligious. Persons professing no religion, no interest in religion; secularists, materialists; agnostics, but not militantly antireligious or atheists.

Atheists. Militantly anti-religious or anti-Christian agnostics, secularists, or marxists.

\section{Section III: Methodology}

Simple regressions are used to determine which individual religions are significantly related to the Globalization Index and stepwise multiple regression is employed to evaluate combinations of religions.

Since religions are correlated, the fraction of the Index explained by a set of them may differ from the total of the fractions explained by the religions individually. Three sets of religions are employed: Christian denominations (Christian, Roman Catholic, Protestant, Anglican, Orthodox, and Independent), Christian types (Christian, Evangelical, Pentecostal/Charismatic, and Great Commission Christians), and non-Christian religions (Muslim, Jewish, Baha'i, Buddhist, Hindu, Ethnoreligionist, Nonreligious, and Atheist).

The Index is regressed on each set separately using stepwise regression to determine the combination of two, three, etc. within each set that provides the greatest explanatory power. Finally, stepwise regression is applied to all the classes to determine the set of religions that explains globalization the best.

To determine whether a larger model increases $\mathrm{R}^{2}$ enough to be significantly better than a smaller model, an $\mathrm{F}$ test is employed:

$$
\mathrm{F}=\left[\left(\mathrm{R}_{\mathrm{L}}^{2}-\mathrm{R}_{\mathrm{S}}^{2}\right) /\left(\mathrm{k}_{\mathrm{L}}-\mathrm{k}_{\mathrm{S}}\right)\right] /\left[\left(1-\mathrm{R}_{\mathrm{L}}^{2}\right) /\left(\mathrm{N}-\mathrm{k}_{\mathrm{L}}-1\right)\right]
$$

where: df $\quad=\left(\mathrm{N}-\mathrm{k}_{\mathrm{L}}-1\right),\left(\mathrm{N}-\mathrm{k}_{\mathrm{S}}-1\right)$

$\mathrm{R}_{\mathrm{L}}^{2} \quad=$ the $\mathrm{R}^{2}$ of the larger model (more religious groups),

$\mathrm{R}_{\mathrm{S}}{ }_{\mathrm{S}} \quad=$ the $\mathrm{R}^{2}$ of the smaller model,

$\mathrm{k}_{\mathrm{L}} \quad=$ the number of groups in the larger model,

$\mathrm{k}_{\mathrm{S}} \quad=$ the number of groups in the smaller model, and

$\mathrm{N} \quad=$ the sample size.

\section{Section IV: Findings}

Table 1 shows the correlation, slope, significance level, and adjusted $\mathrm{R}^{2}$ of the Index regressed individually on each group. The correlation is the Pearson Product-Moment correlation. Remembering that a smaller Index indicates higher ranking, a negative correlation indicates that religion is associated with more globalization.

The slope indicates the change in Index (from 1-62) associated with a one percent increase in the religion's membership. The sign has the same meaning as with correlation. The significance level is indicated to three decimals although some are much more significant than that. In the text, significance levels are reported in parentheses. For example, for each additional percent of Christians in the population, that country's Index changes -0.162 . Christian nations are significantly (.006) more globalized. 
The $\mathrm{R}^{2}$ indicates the proportion of the variation in Index explained by that religion's membership. Adjusted $\mathrm{R}^{2}$ are reported so those that are negative must be interpreted as zero. For example, the percentage of Christians in a nation explains $10.3 \%$ of that country's Globalization Index.

Only three non-Christian groups help to explain globalization. As the percentage of Muslims in a country increases, its globalization significantly (0.002) decreases. As the percentage of nonreligious and atheists populations increase, a nation's globalization significantly (0.035 and 0.077$)$ increases.

Table 1

Simple Regressions on Globalization Index

\begin{tabular}{|l|cccc|}
\hline & Correlation & Slope & $R 2$ & Significance \\
\hline Christians: & & & & \\
All Christians & -0.343 & -0.162 & 0.103 & 0.006 \\
Roman Catholic & -0.033 & -0.016 & -0.016 & 0.801 \\
Protestant & -0.443 & -0.348 & 0.183 & 0.000 \\
Anglican & -0.129 & -0.272 & 0.000 & 0.318 \\
Orthodox & 0.057 & 0.057 & -0.013 & 0.661 \\
Independent & 0.157 & 0.313 & 0.008 & 0.224 \\
Evangelical & -0.175 & -0.499 & 0.015 & 0.172 \\
Pentecostal/Charismatic & 0.155 & 0.231 & 0.008 & 0.228 \\
Great Commission Christians & -0.683 & -0.886 & 0.458 & 0.000 \\
\hline Non-Christian: & & & & \\
Muslim & 0.379 & 0.208 & 0.130 & 0.002 \\
Baha'is & 0.181 & 12.915 & 0.017 & 0.159 \\
Buddhist & 0.142 & 0.165 & 0.004 & 0.270 \\
Jew & -0.104 & -0.192 & -0.006 & 0.421 \\
Jewish (Israel excluded) & -0.184 & -8.174 & 0.017 & 0.156 \\
Hindu & 0.144 & 0.269 & 0.004 & 0.265 \\
Ethnoreligions & -0.054 & -0.095 & -0.014 & 0.677 \\
Nonreligious & -0.268 & -0.604 & 0.056 & 0.035 \\
Atheist & -0.226 & -1.399 & 0.035 & 0.077 \\
\hline
\end{tabular}

Stepwise regression of the Index on multiple denominations results in a two-factor model:

$$
\begin{gathered}
\text { Index }=41.582-0.291 \text { Protestant }-0.106 \text { Christian, } \\
(0.000)(0.003)
\end{gathered}
$$

and a three-factor model:

$$
\begin{gathered}
\text { Index }=40.300-0.291 \text { Protestant }-0.127 \text { Christian }+0.464 \text { Independent. } \\
(0.000) \\
(0.002)
\end{gathered}
$$

(The numbers in parentheses under each equation indicate the significance level of each coefficient.) The coefficients of Protestant and Christian are both negative indicating that the larger each group, the greater the globalization of the country. The positive Independent coefficient means that the more Independents a country has, the less globalized it is. It is interesting to note that Independents do not significantly explain globalization when taken separately. However, after part of the variance in the Index is explained by the other two variables, Independents significantly $(0.043)$ explain the remaining variance. 
The relative size of the coefficients indicate that a given percentage change in Independents has about one and one-half times the impact of the same change in Protestants which in turn has about two and one-half times the impact of Christians. The $\mathrm{R}^{2} \mathrm{~s}$ of models (1) and (2) are 0.216 and 0.257 . F tests show model (1) is significantly (0.000) better than Protestants alone and model (2) is significantly (0.000) better than model (1). No four-factor model does significantly better than (2).

When the Index is regressed on types of Christians, the best model is:

$$
\begin{aligned}
\text { Index }= & 42.212-0.945 \text { Great Commission }+0.410 \text { Pentecostal/Charismatic. } \\
(0.000) & (0.000)
\end{aligned}
$$

The signs of the coefficients indicate that greater percentages of Great Commission Christians and smaller percentages of Pentecostal/Charismatics are related to more globalization. The proportional impact of a given percentage change in the former is more than twice as great as the impact of the same percentage change in the latter. The $\mathrm{R}^{2}$ of 0.525 is significantly $(0.000)$ better than either group alone.

Stepwise regression of the Index on all Christian categories produces the same two-factor model (3). No three-factor model is better.

When the Index is regressed on non-Christian religions, only a two-factor model predicts better than the best single class. It is:

$$
\begin{array}{cc}
\text { Index }= & 25.693+0.210 \text { Muslim }+13.498 \text { Baha'i } . \\
(0.000) & (0.002)
\end{array}
$$

The signs indicate that both religions are related to less globalization. Two observations need to be stressed, however. First, although adding Baha' is to Muslims significantly $(0.048)$ increases the $\mathrm{R}^{2}$ from 0.130 to 0.152 , the Baha'i coefficient is not, by itself, significant. Second, the very large Baha'i coefficient needs to be interpreted with caution. None of the nations in the study has more than 1.2\% Baha'is while Muslims account for up to $98.9 \%$. Therefore, the overall impact of Muslims is greater. Thus, the Baha'i contribution is statistically significant but may not be significant economically, etc.

When all religions are examined model (3) is again the best two-factor model. The best three-factor model for all religions is:

$$
\begin{aligned}
\text { Index }= & 43.672-0.980 \text { Great Commission }+0.448 \text { Pentecostal/Charismatic } \\
& (0.000) \quad(0.000) \\
& -0.322 \text { Ethnoreligion } \\
& (0.041)
\end{aligned}
$$

which has an $\mathrm{R}^{2}$ of 0.550 . The best four-factor model is:

$$
\begin{aligned}
\text { Index }= & 44.619-0.868 \text { Great Commission }+0.546 \text { Pentecostal/Charismatic } \\
& (0.000) \quad(0.000) \\
& -0.375 \text { Ethnoreligion }-0.276 \text { Protestant. } \\
& (0.007) \quad(0.000)
\end{aligned}
$$

with an $R^{2}$ of 0.660 . The best five-factor model is:

$$
\begin{gathered}
\text { Index }=45.744-0.889 \text { Great Commission }+0.532 \text { Pentecostal/Charismatic } \\
(0.000) \quad(0.000)
\end{gathered}
$$




$$
\begin{array}{ccc}
-0.397 \text { Ethnoreligion } & -0.281 \text { Protestant } & -0.333 \text { Jewish. } \\
(0.003) & (0.000) & (0.155)
\end{array}
$$

with an $\mathrm{R}^{2}$ of 0.688 . The best six-factor model, and the best overall model, is:

Index $=50.189-0.752$ Great Commission +0.707 Pentecostal/Charismatic

$$
\begin{array}{ccc}
-0.542 \text { Ethnoreligion }- & 0.260 \text { Protestant }- & 0.391 \text { Jewish } \\
(0.000) & (0.000) & (0.003)
\end{array}
$$

-0.136 Christian.

with a final $\mathrm{R}^{2}$ of 0.727 .

In each of the above, (5-8), the larger model is significantly (0.000) better than the next smaller one. All of the religions appearing, with the exception of the Pentecostal/Charismatic group, are positively associated with globalization. Also, in each case, the impact of a given percentage change in each group is (approximately) in the same order as the entry of the various religions. The Jewish weighting is larger than the Protestant weighting, but except for Israel, no nation has more than two percent Jews. The Pentecostal/Charismatic, Ethnoreligion, and Jewish groups do not significantly explain globalization when examined individually, but when the total variance in the Index is reduced by the other variables, these three each explain a significant portion of the remainder.

\section{Section V: Conclusions}

This paper examines the relationships between the Globalization Index and the worldwide distribution of various religions.

Simple regression results indicate that nations with higher percentages of Christians, Protestants, Great Commission Christians, the nonreligious, and atheists have significantly greater globalization. Muslims populations are negatively related to globalization. Great Commission Christians, by themselves, explain $45.8 \%$ of nations' Globalization Index.

Stepwise regression results indicate that the denominational sets of Protestants, Christians, and Independent Christians explain $25.7 \%$ of the Globalization Index. The Christian types Great Commission Christians and Pentecostal-Charismatics explain 52.5\%\%. The greatest explanation of globalization is found from the percentages of Great Commission Christians, Pentecostal-Charismatics, Ethnoreligionists, Protestants, Jews, and total Christians. Together, these explain an astounding $72.7 \%$ of the variability in globalization across nations.

Although causality is not claimed, most of these world religions have existed for centuries or millennia and globalization is a relatively new concept, so it is logical to conclude that religion impacts globalization and not the other way around.

The ability of the final model to explain $72.7 \%$ of the total variance in the Globalization Index is startling. As far as the author can determine, no one has previously examined the connection between religion and the Globalization Index.

\section{References}

1. "European union gets ready to grow." (2002). Wall Street Journal, Oct. 10, 2002, pp. A12,13.

2. Globalization index. (2002). Washington, D. C.: A. T. Kearney.

3. Gray, J. (2002). "Globalization's last hurrah?" Foreign Policy, Jan/Feb. 2002, pp. 38-51.

4. Lavin, D. (2002). “Globalization goes upscale.” Wall Street Journal, Feb. 1, 2002, p. A18.

5. McMahon, D. (2002). "Born with a soul." Wall Street Journal, Nov. 13, 2002, p. D10.

6. Melloan, G. (2002). "Workers of the world are shedding their chains." Wall Street Journal, Sep. 3, 2002, p. A21.

7. "Skittish travelers cancel trips after bali bombing." (2002) Wall Street Journal, Oct. 15, 02, pp. D1,5.

8. World Christian Encyclopedia $2^{\text {nd }}$. (2001). Vol. 1, NYC: Oxford University Press. 